\title{
Validitas E-Modul Fisika SMA Berbasis Inkuiri Terbimbing Terintegrasi Etnosains untuk Meningkatkan Kemampuan Berpikir Kreatif Peserta Didik
}

\author{
Cici Dwi Tisa Haspen ${ }^{1)}$, Syafriani ${ }^{2)}$, Ramli $^{2)}$ \\ ${ }^{1)}$ Program Studi Magister Pendidikan Fisika, FMIPA Universitas Negeri Padang \\ ${ }^{2)}$ Staf Pengajar Jurusan Fisika, FMIPA Universitas Negeri Padang \\ Keterangan Penulis ${ }^{2)}$ \\ cicihaspen11@gmail.com \\ syafriani@,fmipa.unp.ac.id \\ ramli@,fmipa.unp.ac.id
}

\begin{abstract}
The creative thingking ability of students in high school is still very low. This is due to the ina dequate use of teaching materials. The teaching used are still using printed modules and do not contains steps in the learning model that direct students to be able to improve their creative thingking skills. One of the solutions to improve student's creative thinking skill in physics learning is to use-electronic module (e-module). The e-module which is equipped with a Guided Inquiry Learning Model and Integrated Ethnoscience is a suitable combination to increase creative thinking skills. Through the e-module, students are able to learn independently with the help of ethnoscience in their neighborhood. This study aims to determine the level of validity of the e-module physics based Guided Inquiry Integrated eith Ethnoscience to improve student's Creative Thinking Skills. The type of research is Research and Development (RnD) with the ADDIE development model. But, in this research is limited to the development stage. Because, this research only to see the validity of the product. The instrument used was a validation sheet in the form of an assessment questionnaire by three validators. The data analysis technique used is Aiken $V$ formula. The result validation of e-module an average of 0,83 with the valid category. From the validation results it can be said that Physics e-modul based on guided inquiry integrated with ethnoscience to improve students creative thinking skills meets the valid criteria.
\end{abstract}

Keywords : Inkuiri Terbimbing, Etnosains, Kemampuan Berpikir Kreatif

(C) his is an open access article distributed under the Creative Commons 4.0 Attribution License, which permits unrestricted use, distribution, and reproduction

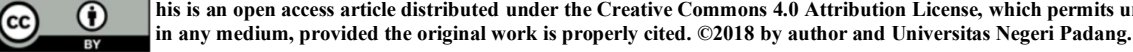

\section{PENDAHULUAN}

Pendidikan adalah suatu hal yang sangat berperan penting dalam kemajuan bangsa. Kurikulum 2013 merupakan kurikulum yang berkembang saat ini di Indonesia. Kurikulum ini diharapkan mampu membawa perubahan yang baik bagi pendidikan di Indonesia. Pembelajaran yang diterpakan pada kurikulum 2013 adalah pembelajaran yang dapat mengembangkan pengetahuan, keterampilan, dan sikap (Asrizal et al, 2018). Melalui kurikulum 2013, pendidik dituntut mampu meningkatkan kualitas pendidikan sehingga menghasilkan peseta didik yang mandiri dan kreatif.

Wabah Covid-19 hingga sekarang masih menyerang dunia, tak terkecuali Indonesia. Akibat wabah ini semua sektor kehidupan mendapat imbasnya, termasuk pendidikan. Banyak sekolah, peserta didik, dan orang tua yang masih bingung melaksakan pembelajaran dalam kondisi tersebut. Banyak sekolah yang hanya memberikan tugas yang ada pada buku cetak dan meminta peserta didik untuk mengerjakan dirumah. Selain itu proses pembelajaran dilakukan melalui grup Whatsapp (WA). Hal tersebut sebenarnya belum bisa mendukung pembelaja- ran online seperti yang diminta oleh pemerintah. Salah satu hal yang dapat mendukung pembelajaran online berjalan adalah dengan menggunakan bahan ajar online. Bahan ajar yang dapat mendukung pembe lajaran online salah satunya adalah Modul Elektronik (E-Modul).

E-Modul adalah bahan ajar berbentuk non- cetak yang dapat digunakan dalam pembelaja- ran. E-modul adalah bentuk modul secara digital dan dikemas dengan lebih menarik. Sama halnya dengan modul, e-modul diyakini mampu membantu peserta didik 
belajar secara aktif dan mandiri (Haspen \& Syafriani, 2020). E-Modul harus disusun secara sistematis artinya modul harus sesuai dengan tujuan pembelajaran yang akan dicapai, karakteristik dan kebutuhan sehingga peserta didik dapat belajar secara mandiri (Asrizal, 2013). Jadi dapat disimpulkan bahwa e-modul merupakan sebuah bentuk non cetak dari modul yang disusun secara sistematis sesuai dengan kebutuhan peserta didik yang bertujuan untuk membantu peserta didik belajar secara mandiri dan dapat digunakan dalam proses pembelajaran.

Pengembagan e-modul disesuaikan dengan model pembelajaran yang sesuai dengan kebutuhan peserta didik. Menurut Lestari (2013) bahan ajar akan lahir dari sebuah rencana pembelajaran yang dibuat oleh peserta didik. Hal tersebut berarti dalam mengem bangkan e-modul peneliti terlebih dahulu harus mengetahui kebu- tuhan yang dibutuhkan oleh peserta didik. Sehingga emodul yang dikembangkan tepat sasaran.

Model pembelajaran yang dapat digunakan bersama dengan e-modul dalah model pembela- jaran Inkuiri Terbimbing. Menurut Hamdayama (2016) inquiry adalah rangkaian kegiatan pembelajaran yang menekankan pada dan menemukan sendiri jawaban dari suatu masalah yang dipertanyakan. Menurut Hanson (2005) model pembelajaran Inkuri memiliki sintak- sintak : Orienation, Ekxploration, Concept Formation, Application, dan Closure. Melalui model pembelajaran Inkuiri Terbimbing peserta didik mampu memecahkan dan menemukan sendiri jawaban dari masalah-masalah yang ditemukan didalam pembelajaran yang tidak lain adalah kemampuan berpikir kreatif dengan tahapantahapan yang ada pada model pembelajaran Inkuiri Terbimbing (Yanti \& Gani, 2016). Pada tahapan Orientation merupakan tahapan persiapan memulai pembelajaran. Eksploration adalah tahapan peserta didik memulai penyelidikan. Concept Formation adalah peserta didik mampu menyusun konsep materi dari penyelidikan yang dilakukan. Application berupa soal- soal latihan yang berguna untuk memperkuat dan menjawab konsep yang telah ditemukan sebelumnya. Closure merupakan tahapan penutup yang merupakan kesimpulan dari materi yang dipelajari peserta didik.

Menurut Putra (2016), model pembe lajaran Inkuiri Terbimbing dapat membantu peserta didik berpikir kreaif dari suatu permasalahan karena model pembelajaran Inkuiri Terbimbing merupakan proses pembelajaran yang mampu memberikan motivasi kepada peserta didik melalui kegiatan pembelajaran sesuai dengan tahapan-tahapan yang ada pada model Inkuiri Terbimbing. Pembelajaran menggunakan model inkuiri terbimbing pendidik tidak melepas peserta didiknya begitu saja. Pendidik harus memberikan arahan dan bimbingan dalam melakukan kegiatan-kegiatan. Jadi dapat disimpulkan bahwa inkuiri terbimbing adalah sebuah model pembelajaran yang bertujuan untuk membentuk pola pikir peserta didik dengan cara menemukan sendiri jawaban atas permasalahan yang diberikan serta pendidik membimbing peserta didik.

Melalui kurikulum 2013 peserta didik diberikan kesempatan untuk belajar dari kebudayaan dan lingkungan sekitar. E-modul yang terintegrasi dengan etnosains (kebuda yaan) mampu meningkatkan kemampuan berpikir kreatif peserta didik. Menurut Arfianti, dkk (2016) pembelajaran berbasiskan pada etnosain dengan mengaitkan materi-materi dan proses pembelaja- rana pada budaya yang ada pada masyarakat setempat mamu membant peserta didik memahami pembelajaran dengan lebih mudah dan etnosains dapat meningkatkan kemampuan kognitif kreatfi, dan kritis peserta didik. Etnosains adalah suatu kegiatan yang mentransformasikan sains asli yang ada di masyarakat. Ruang ling- kup etnosains meliputi bidang sains, pertanian, ekologi, obat-obatan bahkan termsuk flora dan fauna (Rahayu \& Sudarmin, 2015). Etnosains yang ada disekeliling peserta didik akan membantu peserta didik memahami pelajaran dengan mudah karena mereka dapat melihat dan merasakan sains asli yang terkandung didalam masyarakat. Tugas pendidiklah yang harus memampu mentransformasikan etnosains yang ada disekeliling peserta didik. Dalam ilmu fisika, banyak sekali kebudayaan-kebudayaan Minangkabau yang dapat di transformasikan ke dalam bentuk sains ilmiah. Contohnya gerakan Randai yang dapat di integrasikan ke dalam materi gerak melingkar.

Penelitian ini bertujuan untuk mening katkan kemampuan berpikir kreatif peserta didik melalui pengembangan e-modul fisika berbasis inkuiri terbimbing terintegrasi etnosains. Melalui pengembangan e-modul ini diharapkan mampu untuk meningkatkan kemampuan kreatif peserta didik. Menurut 
Rumi \& Syafriani (2020), kemampuan berpikir kreatif adalah potensi dimunculkan atau dikembangkan gagasan baru yang menandai lima aspek yaitu kepekaan, kelancaran, keluwesan, keaslian, dan keterincian. kemampuan kreatif sangat diperlukan dalam era global sekarang ini. Karena orang yang kreatif adalah orang yang mampu menghadapi per putaran zaman.

Dari paparan di atas peneliti ingin mengembangkan sebuah modul elektronik berbasis inkuiri terbimbing terintegrasi etnosains untuk meningkatkan kemampuan berpikir kreatif peserta didik. Berdasarkan uraian tersebut, maka penelitian ini bertujuan untuk menganalisis validitas dari e-modul fisika berbasis inkuiri terbimbing terintegrasi etnosains untuk meningkatkan kemampuan berpikir kreatif peserta didik. Adapun manfaat dari penelitian ini yaitu sebagai sumber belajar yang mengasah kemampuan berpikir kreatif peserta didik, sebagai salah satu sumber belajar yang mengedepankan kreatifitas peserta didik

\section{METODE PENELITIAN}

Jenis penelitian yang digunakan adalah penelitian pengembangan (Research and Development). Penelitian dan pengembangan adalah jenis penelitian yang digunakan untuk menghasilkan produk tertentu dan diuji efektivitas produk tersebut (Sugiyono, 2010). Sedangkan model pengembangan yang digunakan adalah model pengembangan ADDIE. Menurut Januszewki dan Molenda (2008), ADDIE merupakan sebuah pendekatan sistem untuk pengembangan pembelajaran dan prosedur pengembangan dalam pembelajaran. Model pengembangan ADDIE terdiri dari 5 tahapan yaitu, Analyze (analisis), Design (Desain), Development (pengem bangan), Implementation (implementasi), dan Evaluation (evaluasi). Tetapi, pada tahapan ini dibatasi hingga tahapan Development dikarenakan penelitian ini bertujuan untuk melihat validitas produk yang dikembangkan.

Instrumen data validasi dilakukan menggunakan angket validasi. Angket validasi yang disebarkan kepada validator terdiri dari validasi substansi materi, validasi aspek kelayakan penyajian, validasi kebahasaan, dan validasi kelayakan tampilan. Validator yang digunakan adalah 3 orang validator yang terdiri dari 2 orang dosen Fisika dan 1 orang dosen Bahasa Indonesia di lingkungan UNP.
Analisis validasi diuji menggunakan persamaan Aiken's V

$$
V=\frac{\sum s}{[n(c-1)]}
$$

Keterangan :

$$
\begin{aligned}
& \mathrm{s}: \mathrm{r}-l_{o} \\
& l_{o}: \text { angka penilaian validitas terendah } \\
& \mathrm{c}: \text { angka penilaian validitas teringgi } \\
& \mathrm{r}: \text { angka yang diberikan oleh validator } \\
& \mathrm{n}: \text { jumlah penilai }
\end{aligned}
$$

Kategori validitas berdasarkan koefisien Aiken's $\mathrm{V}$ dapat dilihat pada Tabel 1.

Tabel 1. Kategori Validitas Produk

\begin{tabular}{ll} 
Interval & Kategori \\
\hline$\geq 0,61-1,00$ & Valid \\
$<0,61$ & Tidak valid \\
\hline
\end{tabular}

Sumber: (Azwar , 2015)

\section{HASIL DAN PEMBAHASAN}

\section{Hasil Penelitian}

Model pengembangan yang digunakan dalam penelitian ini menggunakan model pengembangan ADDIE yang terdiri dari tahap Analysis, Design, Development, Implemen tation, and Evaluation. Penelitian ini dibatasi sampai pada tahapan Development yaitu untuk melihat valid tidaknya produk yang dikembangkan. Tahapan awal yang dilakukan adalah tahapan Analysis (Analisis).

Tahap analisis dilakukan untuk menganalisis permasalahan yang timbul di lapangan. Tahap analisis terdiri dari analisis kebutuhan peserta didik, analisis kemampuan berpikir kreatif, dan analisis materi pelajaran yang ada disekolah. Dari tahapan analisis tersebut, didapatkan hasil bahwa kebutuhan peserta didik yang terdiri dari 6 aspek, yaitu pengetahuan, keterampilan, kemampuan awal, gaya belajar, sumber belajar, dan motivasi didapatkan rata-rata paling rendah adalah aspek sumber belajar yaitu $62,47 \%$. Hal tersebut mengatakan bahwa sumber belajar yang ada masih kurang. Analisis kemampuan berpikir kreatif peserta didik didapatkan hasil sebesar 74,35 dengan kategori kurang. Sedangkan analisis terakhir adalah analisis materi yang dapat dijadikan sebagai dasar pedoman untuk mengetahui materi yang berkaitan dengan penelitian dan didapatkan ma-terinya yaitu materi SMA Kelas X Semester 1. 
Tahapan selanjutnya adalah tahapan Design (Desain). Tahapan desain dilakukan untuk merancang produk yang akan di kembangkan. Rancangan produk merupa kan hasil dari tahap analisis sebelumnya. Tahap desain dilakukan untuk membuat rancangan e-modul fisika berbasis inkuiri terbimbing terintegrasi etnosains untuk meningkatkan kemampuan berpikir kreatif peserta didik. Perancangan desain e-modul dilakukan sesuai dengan struktur penulisan e- modul. Berikut rancangan e-modul dapat dilihat pada gambar berikut.

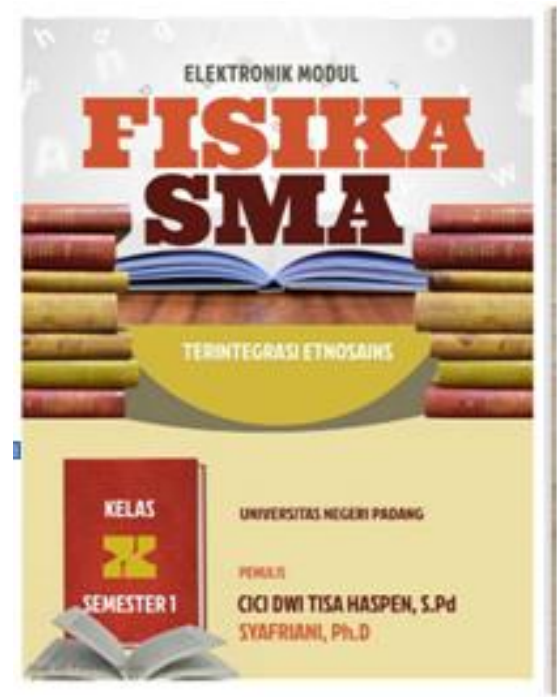

Gambar 1. Tampilan Cover E-Modul

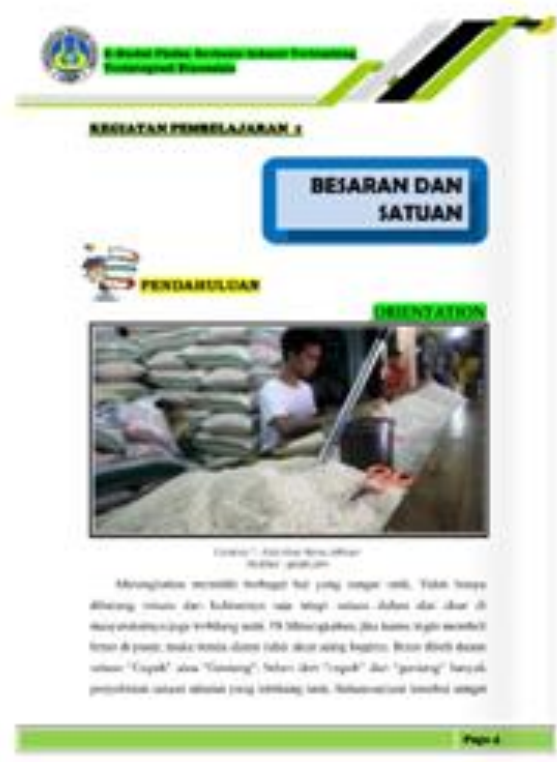

Gambar 2. Tampilan Pendahuluan E-Modul dan Tahapan Inkuiri Terbimbing (Orientasi) dan Gambar pada Pendahuluan Menunjukkan Etnosains

Volume 5| Nomor 1|Mei 2021|Page 95-101
Alat Ukurdi Minangkabau

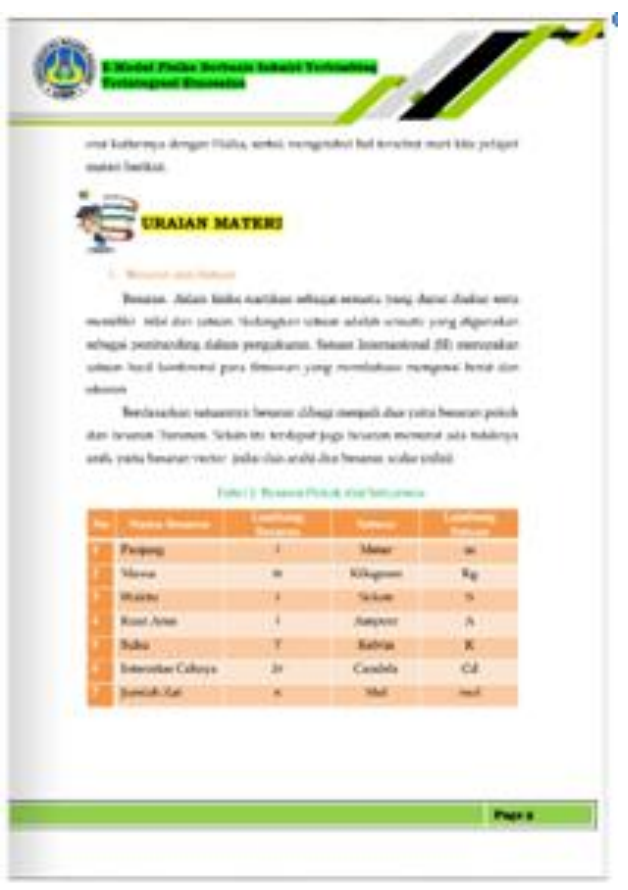

Gambar 3. Tampilan Materi Pembelajaran
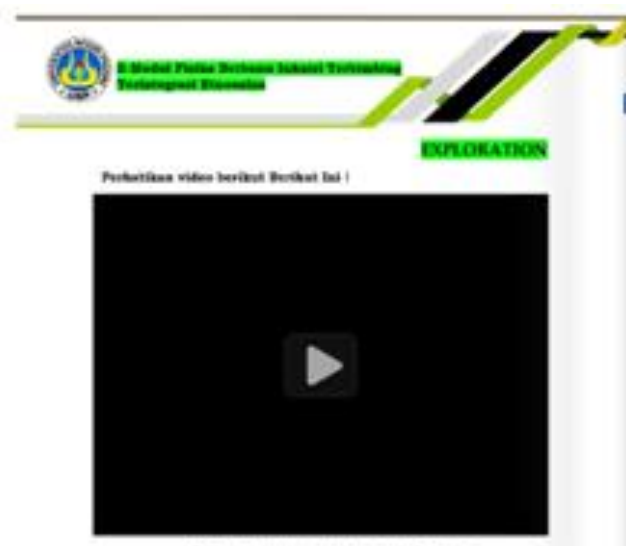

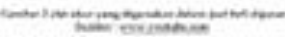

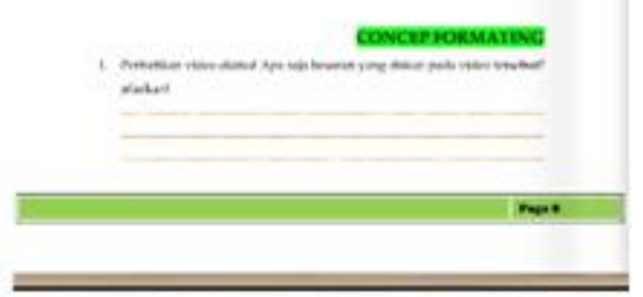

Gambar 4. Tampilan Penugasan yang Di dalamnya terdapat Tahapan Inkuiri Terbimbing dan Video memuat Etnosains 


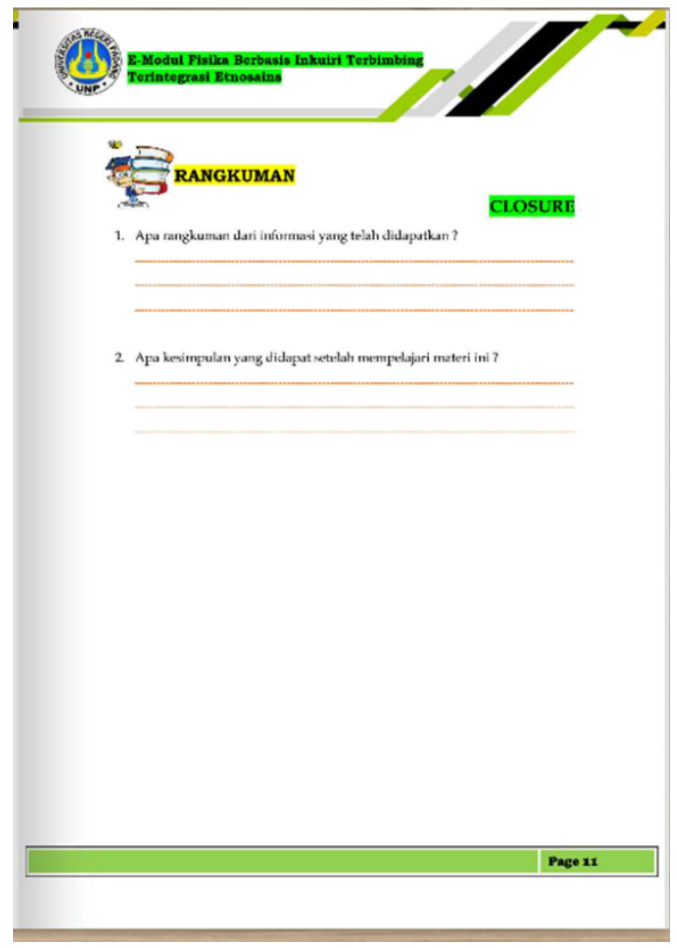

Gambar 5. Tampilan Rangkuman yang di Dalamnya terdapat Tahapan Inkuiri Terbimbing

Setelah desain produk selesai, dilanjutkan dengan tahapan development (pengembangan). Pada tahapan ini dilakukanlah pengembangan terhadap e-modul fisika yang dikembangkan. Hasil rancangan pada tahapan sebelumnya dikembangkan sesuai dengan aturan-aturan yang berlaku untuk mengembangkan sebuah e-modul. Struktur e-modul terdiri dari bagian pembuka, bagian inti, dan bagian penutup. Model Inkuiri Terbimbing terdapat dalam kegiatan inti yaitu di integrasikan kedalam kegiatan pembelajaran. Pada bagian Uraian Materi terdapat tahapantahapan model inkuiri terbimbing. Didalam kegiatan pembelajaran terdapat video dan gambar yang merupakan integrasi dari etnosains. Latihan-latihan dan pertanyaanpertanyaan yang disediakan dalam e-modul berisikan seputar etnosains dan soal-soal yang mampu meningkatkan kemampuan kreativitas peserta didik.

E-modul yang telah dikembangkan kemudian divalidasi oleh beberapa orang validator guna untuk melihat kevalidan dari e-modul yang dikembangkan. Sebelum melakukan validasi e-Modul, terlebih dahulu dilakukan validasi instrumen penilaian validasinya. Validasi instrumen penilaian validasi berguna untuk melihat apakah instrumen penilaian validasi yang digunakan untuk memvalidasi eModul mampu mengukur validasi e-Modul atau tidak. Validasi Instrumen penilaian validasi di validasi oleh 3 orang validator. Setelah hasil validasi instrumen tersebut didapatkan dengan katagori valid maka peneliti dapat melakukan validasi e-modul.

Validasi yang dilakukan terhadap e-modul meliputi 3 validasi yaitu, validasi substansi materi, kelayakan penyajian, kelayakan tampilan, dan validasi kebahasaan. Pada validasi substansi materi terdapat beberapa indikator yang ditampilkan yaitu keakuratan materi yang ditampilkan dalam e-modul sesuai dengan materi fisika, pendukung materi pelajaran, Etnosains, kemampuan kreatif dan tahapan inkuiri terbimbing. Indikator-indikator tersebut apakah sudah sesuai di dalam e-modul atau tidak.

Pada validasi penyajian terdapat beberapa kategori-kategori. Kategori tersebut adalah judul e-modul apakah sudah sesuai dengan aturan seharusnya, kesesuaian antara materi dengan KI dan $\mathrm{KD}$, pendukung penyajian seperti contohcontoh soal mampu dipahami dengan baik oleh peserta didik, dan kelengkapan penyajian.

Validitas kelayakan tampilan memuat beberapa indikator yaitu desain e-modul dan desain isi e-modul. Indikator-indikator yang terdapat di dalam e-modul apakah sudah sesuai dan memiliki desain yang bagus untuk peserta didik. Desain yang bagus akan menarik minat peserta didik untuk mempelajarinya.

Validitas kebahasaan membahas mengenai ketepatan penggunaan bahasa yang sesuai dengan EYD. Simbol-simbol, istilah yang digunakan dalam e-modul tidak membuat peserta didik menjadi ragu. Materi yang ditampilkan dalam emodul harus runtut dan tidak bolak- balik sehingga dalam pembelajaran akan memudahkan peserta didik memahaminya dan yang palig penting bahasa dan materi yang disampaikan sesuai dengan tingkat perkembangan peserta didik.

Selama proses validasi, validator memberikan saran dan masukan terhadap produk yang dirancang. Masukan dan saran sangat berguna bagi peneliti untuk menciptakan e- Modul Fisika yang baik dan valid.

Berikut hasil validasi e-modul fisika berbasis inkuri terbimbing terintegrasi etnosains. 
Tabel 3. Hasil Validitas e-Modul

\begin{tabular}{llc}
\hline No & \multicolumn{1}{c}{ Validasi } & $\begin{array}{c}\text { Nilai } \\
\text { Validasi }\end{array}$ \\
\hline 1 & Substansi Materi & 0,81 \\
2 & Kelayakan Penyajian & 0,85 \\
3 & Kelayakan Tampilan & 0,82 \\
4 & Bahasa & 0,84 \\
\hline & Jumlah & $\mathbf{3 , 3 2}$ \\
& Rata-Rata & $\mathbf{0 , 8 3}$ \\
& Kategori & VALID \\
\hline
\end{tabular}

Berdasarkan Tabel 3 dapat diketahui bahwa rata-rata hasil validasi e-modul sebesar 0,83 dengan kategori Valid. Nilai validasi substansi materi sebesar 0,81 dengan kategori valid. Hal tersebut menunjukan bahwa materi yang terdapat dalam e-modul sesuai dengan fakta, konsep, prinsip, dan prosedur fisika. Nilai validasi kelayakan penyajian adalah 0,85 dengan kategori valid. Hal tersebut mengatakan bahwa penyajian e-modul sesuai dengan aturan-aturan yang berlaku. Nilai validasi kelayakan tampilan adalah sebesar 0,82 dengan kategori valid. Dan nilai validasi kebahasaan adalah sebesar 0,84 dengan kategori valid yang menunjukkan bahwa bahasa yang digunakan didalam e-modul sesuai dengan EYD.

\section{Pembahasan}

Penelitian dilakukan di 3 sekolah negeri yang ada di Pesisir Selatan, yaitu SMAN 1 Ranah Pesisir, SMAN 2 Ranah Pesisir, dan SMAN 1 Linggo Sari Baganti. Penelitian menghasilkan produk berupa e-modul fisika berbasis inkuiri terbimbing terintegrasi etnosains untuk meningkatkan kemampuan berpikir kreataaif peserta didik yang valid. Model pengembangan yang dilakukan adalah model pengembangan ADDIE yaitu Analisis, Desain, Pengembangan, Implementasi, dan evaluasi. Tetapi pada penelelitian ini dibatasi sampai tahap pengembangan karena tujuan penelitian hanya untuk melihat valid tidaknya suatu produk.

Tahapan analisis merupakan tahap awal dalam melakukan penelitian, terdapat tiga aspek yang dianalisis yaitu, analisis kebutuhan peserta didik, analisis kemampuan berpikir kreatif peserta didik, dan analisis materi pembelajaran. Analisis peserta didik dilakukan dengan memberikan angket yang yang dapat diisi oleh peserta didik. Angket tersebut memuat 6 aspek yaitu pengetahuan, keterampilan, kemampuan awal, gaya belajar, sumber belajar, dan motivasi. Hasil yang diperoleh dari analisis kebutuhan peserta didik didapatkan persentase yang kurang. Hal tersebut diakibatkan karena sumber belajar yang ada di tiga sekolah masih kurang. Sumber belajar yang digunakan belum menggunakan bahan ajar non cetak dan belum memanfaatkan teknologi dan internet.

Analisis kemampuan berpikir kreatif dilakukan menggunakan soal-soal yang memiliki indikator kemampuan berpikir kreatif yaitu influency, flexibility, originality, elaboration. Hasil yang diperoleh bahwa kemampuan berpikir kreatif peserta didik masih kurang. Peserta didik belum mampu memunculkan kemampuan kreatifnya dalam pembelajaran maupun dalam kehidupan sehari-hari.

Analisis terakhir adalah analisis materi pembelajaran. Analisis materi yang dilakukan tersebut didapatkan tiga KD yang sesuai dengan aspek kemampuan berpikir kreatif dan etnosains yaitu materi KD 3.2, KD 3.5, dan KD 3.6.

Berdasarkan analisis diatas maka perlu dilakukan pengembagan sumber belajar berupa emodul yang berbasis inkuiri terbimbing terintegrasi etnosains untuk meningkatkan kemam- puan berpikir kreatif peserta didik.

Setelah tahap analisis dilanjutkan dengan tahapan desain. Pada tahapan desain merupakan tahapan untuk merancang produk yang akan dikembangkan yaitu e-modul. Desain e-modul yang dikembangkan harus mengacu pada pedoman pengembangan e-modul.

Tahapan terakhir adalah tahapan pengembangan. Tahapan pengembangan dilakukan uji validitas instrumen dan uji validitas produk. Uji validitas instrumen dilakukan oleh 3 orang ahli dan uji validitas produk di uji oleh 3 orang ahli. Validitas yang diuji dalam tahapan ini terbagi menjadi 4 yaitu, validitas substansi materi, kelayakan tampilan, kelayakan penyajian, dan kebahasaan.

Berdasarkan hasil analisis data penelitian yang telah dilakukan, dapat diketahui bahwa emodul fisika yang dikembangkan memiliki kriteria valid dengan tingkat kevalidan yang diperoleh sebesar 0,83. Menurut Azwar (2015), sebuah produk dikatakan valid apabila memiliki kategori sebesar $<0,61$. Hal ini sejalan dengan penelitian yang dilakukan oleh Primadi (2018), melakukan penelitian yang serupa dengan judul Pengembangan E-Modul Fisika Berbasis inkuiri terbimbing untuk meningkatkan kemampuan 
berpikir kreatif peserta didik pada materi listrik dinamis dengan kategori valid. Selain itu penelitian serupa yang mengatakan bahwa model Inkuiri terbimbing mampu meningkatkan kemampuan berpiki kreatif peseta didik juga dilakukan oleh Yanti, dkk (2016).

Dengan demikian, secara keseluruhan emodul fisika berbasis inkuiri terbimbing terintegrasi etnosains untuk meningkatkan kemam-puan berpikir kreatif peserta didik berkategori valid dan baik digunakan baik dari segi kelayakan materi, kelayakan penyajian, kelayakan tampilan dan layak juga digunakan secara bahasa.

\section{KESIMPULAN}

Berdasarkan hasil penelitian yang telah dilakukan oleh peneliti dapat disimpulkan bahwa E-modul fisika berbasis Inkuiri Terbimbing Terintegrasi Etnosains untuk meningkatkan kemampuan berpikir kreatif peserta didik memiliki kriteria valid dengan rata-rata hasil validasi adalah 0,83 . Hal tersebut dapat diartikan bahwa e- modul fisika berbasis inkuiri terbimbing terintegrasi etnosains untuk meningkatkan kemampuan berpikir kreatif peserta didik valid dan dapat digunakan dalam pembelajaran disekolah.

\section{UCAPAN TERIMAKASIH}

DIPA Direktorat Riset dan Pengabdian Masyarakat Kementrian Riset, Teknologi dan Pendidikan Tinggiberdasarkan surat penugasan pelaksanaan Tahun Anggaran 2020 No.882/UN35.13/LT/2020 dengan Ketua Tim Syafriani, Ph.D.

\section{DAFTAR PUSTAKA}

Arfianti, S., Sudarmi, M., \& Sumarni, W. (2016). Model Pembelajaran Kimia Berbasis Etnosains untuk Meningkatkan Kemampuan Berikir Kritis siswa. Jurnal Pengajaran MIPA, 21(1) 46-51.

Asrizal,A. dkk. (2013). "Pembuatan Modul Fisika Berbasis TIK Untuk Mengintegrasikan Nilai Pendidikan Karakter dalam Pembelajaran Siswa SMAN 10 Padang Kelas X Semester 1". Jurnal Pillar Of Physics Education, Vol. 1. Hal. 30-38

Azwar, Saifuddin. 2015. Reliabilitas dan Validitas Edisi IV, Cetakan IV. Yogyakarta: Pustaka Pelajar.
Hamdayama. 2016. Metodologi Pengajaran. Jakarta : PT. Bumi Aksara.

Hanson. David. 2005. Designing ProcessOriented Guided-Inquiry Activities. New York : Pacific Crest.

Haspen, C. D. T., \& Syafriani. 2020. The Preliminary Study in The Development of E-Physics Module Integrated Ethnoscience. The $2^{\text {nd }}$ International Conference on Research and Learning of Physics.

Januszewski, A. \& Molenda, M. 2008. Educational Technology: A definition with commentary. New York: Lawrence Erlbaum Associates.

Lestari, Ika. 2013. Pengembangan Bahan Ajar Berbasis Kompetensi. Padang: Akademia.

Primadi. M.R., Sarwanto, Suparmi. 2018. Pengembangan Modul Fisika Berbasis Inkuiri Terbimbing untuk Meningkatkan Kemampuan Berpikir Kreatif Siswa Pada Materi Listrik Dinamis. M JRKPF UAP. 5(1), 1-9.

Putra, Redza D dkk (2016. Peningkatan Kemampuan Berpikir Kreatif Siswa Melalui Model Pembelajran Inkuiri Terbimbing pada Siswa Kelas XI MIA 1 SMA Negeri Colomadu Karanganyar Tahun Pelajaran 2015/2016. Proceeding Biology Conference. 13(1):330-334.

Rahayu, W. E., \& Sudarmin. 2015. Pengembangan Modul IPA Terpadu Berbasis Etnosains Tema Energi dalam Kehidupan Untuk Menanmkan Jiwa Konservasi Siswa. Unnes Science Educational Journal, 4(2).

Rumi, Yuliska \& Syafriani. 2020. Efektifitas Pengembangan LKPD Fisika SMA/MA Berbasis Inquiry Training Untuk Meningkatkan Kemampuan Berpikir Kreatif Peserta Didik.

Sugiyono. 2010. Metode Penilitian Pendidikan: Pendekatan Kuantitatif, Kualitatif dan $R \& D$. Bandung:Alfabeta.

Yanti, N. S., Yusrizal \& Gani, A. (2016). Penerapan Model Pembelajaran Inkuiri Terbimbing untuk Meningkatkan Kemampuan Berpikir Kreatif dan Motivasi Siswa Ditijau dari Jenis Kelamin Pada Materi Kalor Kelas X SMAN 11 Banda Aceh. Jurnal Pendidikan Sains Indonesia. 